\title{
Occupations, National Identity, and Immigrant Integration
}

Comparative Political Studies 20I7, Vol. 50(2) 232-263

(C) The Author(s) 2016

Reprints and permissions: sagepub.com/journalsPermissions.nav DOI: $10.1177 / 00104 \mid 4016655535$ journals.sagepub.com/home/cps

(S)SAGE

\section{Rahsaan Maxwell'}

\begin{abstract}
This article examines strategies for immigrants to improve integration by exploring the relationship between occupational choice and assimilation. I ask whether immigrant-origin individuals will be viewed as better representatives of the nation when employed in occupations that reflect national identity. I examine this question with data from original surveys in France, Germany, and the United States. Results suggest that native and immigrant-origin individuals in occupations that reflect national identity are more likely to be seen as ideal representatives of the nation. Yet, the benefits of an occupation that reflects national identity are fairly minor for immigrant-origin individuals in France and Germany and roughly one third the size of the benefit for native-origin individuals. In comparison, native and immigrant-origin individuals in the United States have the same increase in likelihood of being seen as ideal representatives of the nation. These findings have implications for our understanding of immigrant integration and national identity.
\end{abstract}

\section{Keywords}

occupation, national identity, immigration, immigrant integration, Europe, United States

\footnotetext{
'University of North Carolina at Chapel Hill, NC, USA
}

\section{Corresponding Author:}

Rahsaan Maxwell, Department of Political Science, University of North Carolina at Chapel Hill, 322 Hamilton Hall, CB 3265, Chapel Hill, NC 27599, USA.

Email: rahsaan@email.unc.edu 


\section{Introduction}

Immigrant integration is a complicated process. Natives are likely to stigmatize and ostracize immigrants when they believe that immigrants are not sufficiently committed to assimilation (Goodman, 2012; Joppke, 2007; Sniderman \& Hagendoorn, 2007). However, when immigrants feel marginalized, they often protest by withdrawing from mainstream society and potentially engaging in riots, terrorist attacks, and targeted political assassinations (Dancygier \& Laitin, 2014). Natives' negative attitudes and immigrants' selfsegregation can quickly reinforce each other and perpetuate a vicious cycle of failed integration that is difficult to break (Adida, Laitin, \& Valfort, 2014). Given these high stakes, a key question for societies around the world is the conditions under which immigrants are more likely to successfully integrate and become part of the national community?

One strand of research identifies the demographic characteristics of immigrants who are more likely to be accepted. This research finds that immigrants who have the same skin color, race, or religion as natives are more likely to be accepted (Aalberg, Iyengar, \& Messing, 2011; Helbling \& Traunmüller, 2016). Immigrants are also more likely to be accepted if they come from countries considered culturally compatible with the host society (Hainmueller \& Hangartner, 2013; Wimmer \& Soehl, 2014). In addition, immigrants who arrive legally are viewed as more legitimate members of the national community (Wright, Levy, \& Citrin, 2016). These demographic characteristics are in some respects the main fault-lines of integration because they structure integration prospects from the moment an immigrant enters the country. However, these characteristics are mostly fixed and impossible to change.

Another strand of research examines strategies immigrants can pursue to improve their integration prospects despite having the "wrong" national origins, race, religion, or skin color. For example, immigrants who learn the host country language are more likely to be accepted (Enos, 2014; Newman, Hartman, \& Taber, 2012), even if they speak with an accent (Hopkins, 2015). In addition, research suggests that immigrants can increase their likelihood of acceptance by signaling their desire to assimilate and adopting host country cultural practices (e.g., clothing choices or food consumption practices; Alba $\&$ Nee, 2003; Tribalat, 1995). Immigrants can also create formal ties to the host society by intermarrying with natives or promote intergenerational assimilation by giving their children names that are common among natives (Goldstein \& Stecklov, 2016; Sue \& Telles, 2007). Finally, evidence suggests that immigrants who achieve high levels of socio-economic status are more likely to be accepted (Hainmueller \& Hopkins, 2015). 
I build on research about strategies for immigrants to improve their integration prospects by exploring the relationship between occupational choice and assimilation. I extend the common assumption that occupation is a central component of identity to propose that national identity is reflected in certain occupations. My central research question is whether immigrant-origin individuals will be viewed as better representatives of the nation when employed in occupations that reflect national identity. I examine this question with data from original online surveys in three countries: France, Germany, and the United States. I use the cross-national comparison to explore how immigrant integration dynamics may depend on the country context.

My results suggest that individuals in occupations that reflect national identity are more likely to be seen as ideal representatives of the nation. These benefits exist for native as well as immigrant-origin individuals and are present in each of the three country contexts. Yet, there is evidence of cross-national variation in immigrant integration dynamics. Most notably, the benefits of being in an occupation that reflects national identity are fairly minor for immigrant-origin individuals in France and Germany and roughly one third the size of the benefit for native-origin individuals. In comparison, native and immigrant-origin individuals in the United States have the same increase in likelihood of being seen as ideal representatives of the nation when in occupations that reflect national identity.

These findings have several implications for our understanding of immigrant integration and national identity. First, there is evidence of successful immigrant integration in France, Germany, and the United States as immigrant and native-origin individuals have the same likelihood of being considered an ideal representative of the nation when in occupations that do not reflect national identity. This is an important corrective to dramatic popular perceptions of immigrant integration as a complete failure (Caldwell, 2009; Huntington, 2004). However, the results also suggest that important boundaries remain between immigrants and natives in France and Germany, where immigrant-origin individuals do not benefit from being in occupations that reflect national identity. This is most likely because national identity is more ethnocentric in France and Germany than in the United States, which may indicate ongoing integration challenges in those countries (Alba \& Foner, 2015).

This article also proposes a new way of understanding occupation both in relation to immigrant integration and national identity. Most research on attitudes toward immigrants in different occupations asks how natives evaluate the economic contributions to society of immigrants in different occupations (Hainmueller \& Hiscox, 2010). Those economic considerations are juxtaposed with cultural considerations about whether immigrants are sufficiently assimilated, which tend to be measured through indicators like language 
proficiency and religious and cultural practices (Hainmueller \& Hopkins, 2014). My findings suggest that this juxtaposition may be overly simplified because occupational choice has economic implications for the economy but it is also a cultural practice with implications for how immigrants are viewed in relation to national identity. Finally, I offer a new perspective on how national identity operates. One of the major themes of recent research on national identity is an exploration of the multiple ways in which national identity can be deployed and experienced in everyday life (Billig, 1995; Huddy \& Khatib, 2007; Yogeeswaran \& Dasgupta, 2014). I build on that research by proposing that occupations are an important way of understanding how national identity is signaled and how community boundaries are maintained.

\section{Occupation and National Identity Boundaries}

I begin with the assumption that occupation is a central component of identity. We know occupation shapes societal hierarchies via the relationships between occupation, wealth, and socio-economic status (Hauser \& Featherman, 1977; Rose \& Harrison, 2010). In addition, work is one of the main ways in which people contribute to society and thereby position themselves in relation to the rest of society (Dunkerley, 2013). Finally, occupations are associated with different character traits due to the qualification and actions required. For example, nurses are generally considered caring and nurturing while used car salesmen are generally considered manipulative and untrustworthy. The relationship between occupations and specific character traits shapes how individuals perceive themselves as well as how they are perceived by the rest of society (Bourdieu, 1987; Corneo \& Jeanne, 2010).

I extend insights about the connection between occupation and identity by exploring how occupations may also be related to national identity. National identity is a multifaceted concept that simultaneously captures who we think we are as a nation, who we think we should be as a nation, and what makes us distinct from other nations (Smith, 1991). The content of national identity comes from many sources, including geography, values, language, race and ethnicity, symbols, habits, and behaviors (Anderson, 1983; Orgad, 2015). Given the diverse components of national identity, it is an inherently subjective concept that is interpreted in different ways by different people (Billig, 1995; Wright, 2011a). Nonetheless, there is usually consensus on the broad contours of national identity (Li \& Brewer, 2004; Schildkraut, 2010; TheissMorse, 2009). Therefore, I claim that some occupations are more likely than others to reflect the prevailing understanding of national identity.

I propose that if national identity can be reflected in certain occupations, then people in those occupations should be more likely to be viewed as 
representative of the nation. Everyone has multiple identities but the identities that become most salient in any given situation are the ones that are actively primed (Blumer, 1969; Ross \& Nisbett, 1991; Tajfel, 1974). Therefore, when an individual is identified by his or her occupation and that occupation reflects the national identity, the likelihood of identifying that person with the nation should increase. Note that this purported association does not require thelikely untenable - assumption that only people in occupations that reflect national identity can be viewed as legitimate representatives of the nation. Instead, I focus on the marginal benefit of being in an occupation that reflects national identity. The benefit to the relationship between occupation and national identity may be especially important for immigrants because their foreign origins often leave them excluded from the national community despite having seemingly objective measures of integration like citizenship (Bail, 2008; Koopmans, Statham, Giugni, \& Passy, 2005).

\section{Generating Hypotheses}

The central research question in this article is whether immigrant-origin individuals are more likely to be viewed as representatives of the national community when employed in occupations that reflect national identity. One hypothesis is that immigrant-origin individuals will not benefit from working in occupations that reflect national identity. This logic begins with the assumption that natives are predisposed to view immigrant-origin individuals as outside the national community because of their foreign origins (Bail, 2008; Schildkraut, 2014; Wong, 2010). As a result, natives may disregard cues about an immigrant's assimilation because they are counter-stereotypical (Brown, 2010; Stangor \& Ford, 1992). Instead, natives will focus on foreign origins as the most prominent and relevant aspect of the immigrant's identity. This leads to the following hypothesis.

Hypothesis 1 (H1): Immigrant-origin individuals are not more likely to be considered representative of the nation when employed in occupations that reflect national identity.

A second possibility is that immigrant-origin individuals will be viewed as better representatives of the nation when employed in occupations that reflect national identity. The logic here is that immigrants can use blatant displays of attachment to the host society to compensate for their foreign origins (Wright \& Citrin, 2011). Immigrants' demonstrations of commitment to the national culture may be especially successful if they draw on symbols of national identity that are emotionally and psychologically powerful for natives (Butz, 
2009; Schatz \& Lavine, 2007). Moreover, research suggests that under some circumstances people may have particularly strong and positive reactions to stereotype incongruent cues about an out-group (e.g., immigrants waving the host country flag, or in the case of this study, immigrants in an occupation associated with the host country national identity) because they are unexpected (Bettencourt, Dill, Greathouse, Charlton, \& Mulholland, 1997; Kernahan, Bartholow, \& Bettencourt, 2000; Mendes, Blascovich, Hunter, Lickel, \& Jost, 2007). This leads to the following hypothesis.

Hypothesis 2 (H2): Immigrant-origin individuals are more likely to be considered representative of the nation when employed in occupations that reflect national identity.

A third possibility is that reactions to immigrant-origin individuals in occupations that reflect national identity will vary across country contexts. This line of argumentation builds on research about how different conceptions of national identity and different conditions for membership in the national community shape immigrant integration (Koopmans et al., 2005; Reeskens \& Wright, 2013). In recent years, there has been a dramatic increase in the number of typologies and measurement schemes to operationalize national approaches to citizenship, ${ }^{1}$ but the main underlying distinction is between countries that are more or less ethnocentric in their approach to integrating newcomers (Brubaker, 1992; Wright, 2011b). This distinction is important because when national identity is based around ethnocentric markers, it will be harder for immigrant-origin individuals who are ethnically or racially different from natives to become full members of the national community (Flores, 2015; Wright, 2011a). Therefore, one might expect that immigrant-origin individuals will be more likely to benefit from working in occupations that are reflective of national identity in countries where national identity is less ethnocentric, and therefore more open to immigrants demonstrating their connection to the nation in ways other than ethnic heritage.

Hypothesis 3 (H3): Immigrant-origin individuals are more likely to benefit from being employed in occupations that reflect national identity in countries where national identity is less ethnocentric.

\section{Data}

I evaluate hypotheses about natives' attitudes toward immigrants with a series of original online surveys in France, Germany, and the United States. ${ }^{2}$ 
All three countries have diverse sets of immigrant-origin groups and intense public debates about the best way to promote successful immigrant integration. In addition, all three countries have particular concerns about the integration of non-European origin immigrants, who are the focus of this article (Dancygier, 2010; Hochschild \& Mollenkopf, 2009; Maxwell, 2012).

The selection of France, Germany, and the United States is particularly useful for evaluating $\mathrm{H} 3$ because it provides variation in the extent to which national identity is ethnocentric. Among Western countries with large immigrant populations, Germany is often considered a classic case of national identity based on ethnic heritage (Brubaker, 1992). Throughout the 20th century, access to German citizenship was difficult to obtain without ethnic German heritage, even for children born in Germany to immigrant parents. Since 2000, German nationality law has been modified to allow more opportunities for immigrants (or children of immigrants) without ethnic German heritage to become citizens. Yet public perceptions of who is legitimately German are often still based on ethnic origins (Ditlmann, Purdie-Vaughns, \& Eibach, 2011; Koopmans et al., 2005). In contrast, ethnicity has been much less important for national identity in the United States. This is primarily because one of the central narratives about American identity is that the country was founded through waves of continued immigration from diverse countries and cultures of origin (Schildkraut, 2010, 2014; Theiss-Morse, 2009). This does not mean that ethnicity is irrelevant in American society. Instead, the key point is that ethnicity is much less central to American national identity than in other countries (Alba \& Foner, 2015). France is an in-between case. Historically France was distinct from many other European nations because of the strong civic legal tradition that granted citizenship to people born in France or living in France, irrespective of their ethnic origins (Brubaker, 1992). However, France is also distinct in its strong emphasis on immigrant assimilation, which privileges the preexisting French ethnic cultural norms (Noiriel, 1988). Moreover, many critics note that the popular conception of who is legitimately French is often ethnocentric (Fassin \& Fassin, 2006).

In each survey, I limit my analysis to native-origin respondents. ${ }^{3}$ This requires screening out individuals who were not born in the country of residence as well as screening out individuals born in the country of residence but with immigrant origins. I analyze a final sample of 1,008 native-origin respondents in France, 1,001 in Germany, and 387 in the United States. ${ }^{4}$

\section{Measuring Attitudes Across Occupations}

Each respondent receives a series of vignettes describing characters in different occupations. For each vignette, respondents answer a question about how 
Table I. Occupations and National Identity.

\begin{tabular}{lll}
\hline & Reflective of national identity & Not reflective of national identity \\
\hline France & $\begin{array}{c}\text { Chef, winemaker } \\
\text { Chef, winemaker, brewer, } \\
\text { symphony }\end{array}$ & $\begin{array}{l}\text { Banker, civil servant } \\
\text { Banker, civil servant, retail }\end{array}$ \\
United States & $\begin{array}{l}\text { Entrepreneur, inventor } \\
\text { Chef, symphony, winemaker }\end{array}$ \\
\hline
\end{tabular}

well the character "corresponds to the ideal image you have of a French/ German/American person?"5 This question captures a high level of immigrant integration. It goes well beyond measuring whether natives believe that immigrants have the right to live in the same society and be a part of the same territorial space. Instead, it builds on literature that argues for a deeper conception of true belonging (Koopmans et al., 2005), by measuring the extent to which immigrant-origin individuals are seen as legitimate representatives of the nation.

To measure how attitudes may vary across different occupations, the vignettes describe characters in two types of occupations: those that reflect national identity and those that do not. To select occupations, I begin by consulting secondary literature on national identity in each country. There is no literature (to my knowledge) that explicitly analyzes the relationship between occupations and national identity. Instead, I look for the prominent values, symbols, and traditions of each national identity and then select occupations that are closely associated. The occupations are summarized in Table 1.

For France, there is a considerable amount of literature suggesting that wine and cuisine are central to national identity (DeSoucey, 2010; Ferguson, 1998; Guy, 2007), so I select chefs and winemakers as occupations that reflect French national identity. ${ }^{6}$ Literature suggests that food and wine are also important for German identity and, to expand the set of occupations, I also include brewers and symphony employees because beer and classical music are two domains that have special resonance for German identity (Lepenies, 2006). Secondary literature about the United States suggests several traits that are strongly associated with national identity, including industriousness, independence, individualism, materialism, optimism, and arrogance (Alba \& Nee, 2003; Ditlmann et al., 2011; Schildkraut, 2010). However, it was not immediately apparent how these cultural traits would be reflected in an occupation. Therefore, I conducted a pilot study on MTurk on March 26 and 27, 2014, and included an open-ended question that asked "Which occupations are quintessentially American and reflective 
of our cultural identity?" The two most common responses were entrepreneur and inventor, which is consistent with the research emphasizing industriousness, independence, and individualism. ${ }^{7}$

The far right column of Table 1 lists occupations that do not reflect any of the elements of national identity found in my review of literature on each country. These occupations need to be general enough that respondents would be familiar with them, and there need to be high- and lowstatus versions of each occupation (this is a necessary feature of my research design as described in the next section). ${ }^{8}$ Given my selection of chef and winemaker as occupations that reflect national identity in France and Germany, I use them as occupations that do not reflect national identity in the United States. This is consistent with existing literature about identity in the United States. ${ }^{9}$ Selecting chef and winemaker as occupations that do not reflect national identity in the United States is also a useful test of my claim that occupations should be interpreted through the national cultural context. If there are intrinsic characteristics to chefs and winemakers that make people view them as better representatives of the nation, we would see that dynamic in all three countries. However, if chefs and winemakers are only viewed as better representatives of the nation in countries where they are reflective of national identity, we would see them viewed more positively in France and Germany but not in the United States.

The primary function of the occupations in Table 1 is to test $\mathrm{H} 1, \mathrm{H} 2$, and $\mathrm{H} 3$ with variation in the extent to which occupations reflect national identity within each country. The list is not intended to be exhaustive of occupations that do (or do not) reflect national identity. In addition, I make no assumptions about the relative strength of the connection to national identity for occupations across the three countries. Nonetheless, to the extent that there is significant variation in the connection to national identity across occupations within each country, I should be able to observe whether immigrant-origin individuals' benefit to being in an occupation that reflects national identity varies across countries where national identity is more or less ethnocentric.

\section{Experimental Design}

Each respondent receives a series of vignettes, one for each of the occupations (four vignettes in France, seven in Germany, and five in the United States). The substance of the vignettes varies according to a $2 \times 2$ betweensubjects design in each country. In each country, respondents are randomly assigned to either receive vignettes that all describe native-origin 
characters or vignettes that all describe immigrant-origin characters. ${ }^{10}$ This design provides a benchmark for reactions to immigrant-origin individuals. For example, I may find that immigrant-origin individuals are just as likely to be considered ideal representatives of the nation whether or not the occupations reflect national identity. Without a comparison with native-origin individuals, we would have no way of knowing if that was because the relationship between occupations and national identity does not matter in general, or if immigrant-origin individuals face unique barriers to benefiting from the association between occupation and national identity. In each country, I use a prominent non-European-origin immigrant group (Blacks in France, Turks in Germany, and Latinos in the United States). I select non-European-origin groups because they are the center of debates about immigrant integration in each country. This also allows me to focus on the possibility for occupational choice to serve as an integration strategy among some of the hardest possible cases: groups with the "wrong" national and racial or ethnic origins. ${ }^{11}$

The second axis of randomization is whether respondents receive vignettes with all high or low socio-economic versions of the occupations. This is necessary to examine how the relationship between occupations and national identity may vary according to socio-economic status, which is one of the most prominent ways that occupation is analyzed in research on attitudes toward immigrants (Hainmueller \& Hiscox, 2010; Helbling \& Kriesi, 2014).

The $2 \times 2$ between-subjects design obscures the fact that respondents are being analyzed for how they evaluate individuals with or without immigrant origins and with different socio-economic status. If respondents were aware of those comparisons, they might alter their responses to avoid appearing biased. ${ }^{12}$ This research design is focused on variation across occupations, immigrant origins, and socio-economic status. ${ }^{13}$ Beyond those three variables, the vignettes are designed to be as similar as possible across occupations. In each case, the vignettes describe someone who is moderately successful and therefore potentially likable, although not so successful that he is impossible to relate to for the average subject.

In summary, each respondent receives a series of vignettes (one for each occupation). The substance of the vignettes is one of four conditions that are randomly assigned across respondents within each country. Therefore each respondent receives vignettes that are either all high-status immigrant-origin characters, all low-status immigrant-origin characters, all high-status nativeorigin characters, or all low-status native-origin characters. The order of the vignettes is randomized across respondents within each country. The wording for the French vignettes is as follows. 
Banker: Laurent Bourg is [a bank teller/the head of an important banking firm]. He loves all the details of the finance industry and hopes to work for his own benefit but also the benefit of his bank and his clients.

Chef: Christophe Aubry [is an untrained chef/became a chef after receiving a prestigious degree in culinary arts]. He has worked in several restaurants and one day hopes to open his own restaurant.

Civil service: Jean-Louis Perret [is a civil service executive/works at the counter of a civil service department]. He gets along well with his colleagues and is very attached to his department.

Winemaker: Maurice Giraud [is an untrained winemaker/is a winemaker with a diploma in Enology and] who leads a team that works with him. He hopes that his wines will be very successful.

The wording for the German vignettes is as follows

Banker: [Klaus Schmidt/Cemal Kutlu] is [the head of an important banking firm/a bank teller]. He loves the finance industry and hopes to work for his own benefit but also the benefit of his bank and his clients.

Brewer: [Felix Nagel/Toygar Uysal] is [the head of/an administrative assistant for] a large brewery. He enjoys being a part of a company that makes delicious beverages that people have fun drinking.

Chef: [Andreas Fuchs/Emin Yağci] is a [executive chef/line cook]. He is motivated by the ability to serve people food that pleases their senses and brightens their day.

Civil service: [Martin Bauer/Fatih Özhan] is a [civil service executive/works at the window of a civil service office]. He believes in the work of the government and is happy to serve the public.

Retail: [Rolf Lang/Hasan Remzi] is a [high-level executive/cashier] for a large retail company. He is passionate about sales and wants to connect the public with great products.

Symphony: [Lukas Koch/Soner Demir] is a [top executive/secretary] for a major symphony. He is proud to help bring great classic music to the public.

Winemaker: [Konrad Werner/Cem Karadag] [owns his own winery/is a winery assistant] and is passionate about getting the best expression of his grapes and his land, every vintage. 
The wording for the U.S. vignettes is as follows

Chef: [Pedro Rodriguez/Phillip Rogers] [is an untrained chef/became a chef after receiving a prestigious degree in culinary arts]. He is motivated by the ability to serve people food that pleases their senses and brightens their day.

Entrepreneur: [Miguel Gutierrez/Michael Green] is an entrepreneur. He started his own business after [receiving a master of business administration degree/ dropping out of high school]. He looks for ways to improve efficiency, which allows him to increase profits and lower costs for his customers.

Inventor: [Juan Hernandez/John Henderson] is an inventor. He began building machines [when he dropped out of high school/after completing his $\mathrm{PhD}$ in physics]. He uses computers to help with our household chores and wants to make everyday life easier for average people.

Symphony: [Diego Perez/Donald Peters] is a [top executive/secretary] for a symphony orchestra. He is proud to help bring great classical music to the public.

Winemaker: [Carlos Lopez/Charles Lewis] [is a winemaker who owns his own winery/is a winery assistant] and is passionate about getting the best expression of his grapes and his land, every vintage.

\section{Results: Representing the Nation Across Occupations}

Figure 1 presents the mean score on the dependent variable for immigrant and native-origin vignettes among occupations that either do or do not reflect national identity. ${ }^{14}$ In all three countries, native and immigrant-origin individuals are more likely to be considered ideal representatives of the nation when in occupations that reflect national identity. This is consistent with $\mathrm{H} 2$ and suggests that there may be an important connection between occupational choice and national identity. However, there is also evidence of crossnational variation and support for $\mathrm{H} 3$. In France and Germany, there is only a slight increase in the likelihood of being considered an ideal representative of the nation for immigrant-origin individuals in occupations that reflect national identity, while the increase for native-origin individuals is roughly 3 times larger. In the United States, immigrant and native-origin individuals receive similar increases when in occupations that reflect national identity.

To formally test the above interpretation of the findings in Figure 1, I estimate a series of regression models. Each respondent answered a series of vignette 


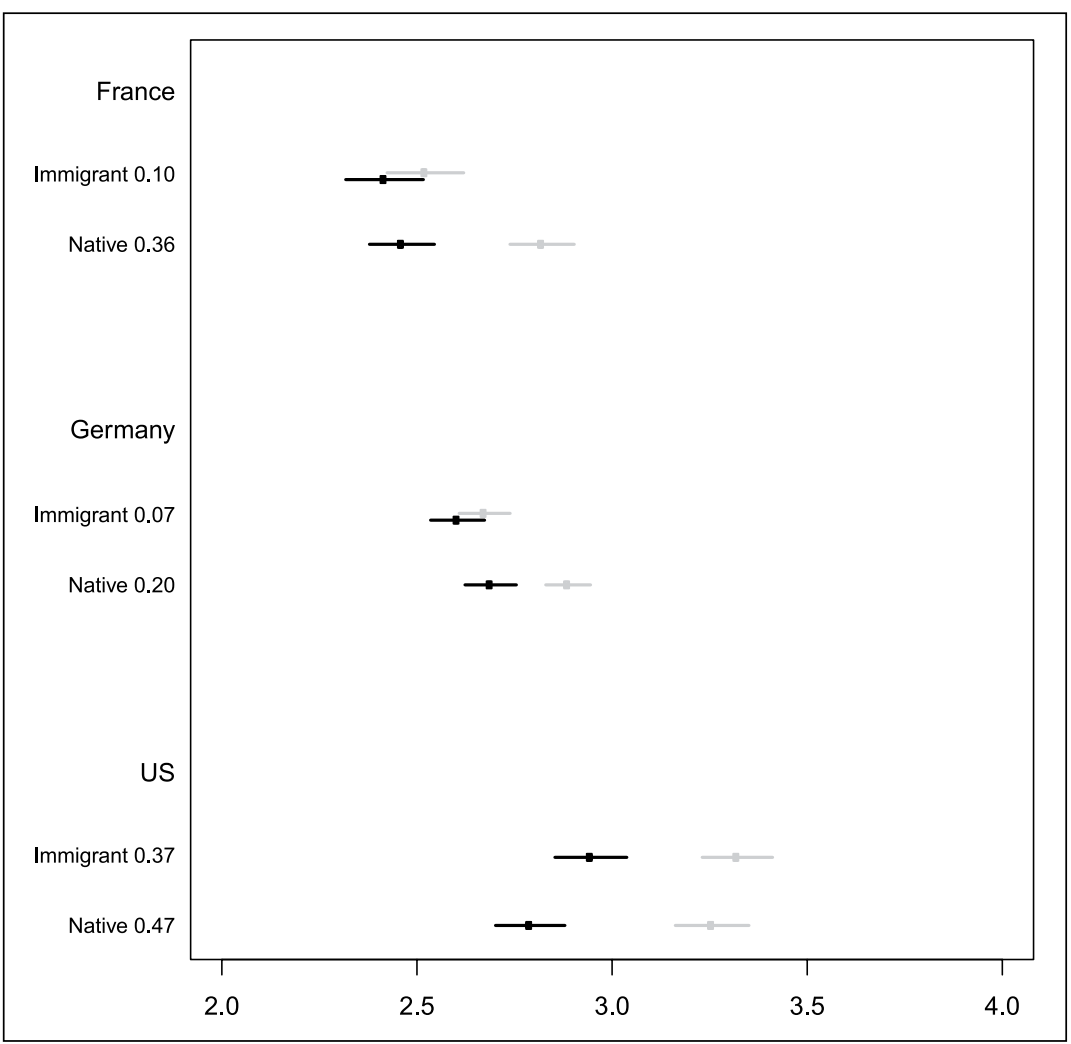

Figure I. Mean scores for the ideal image of a French/German/American person across immigrant and native-origin vignettes and across occupations.

The dependent variable is coded $0=$ very poorly, $I=$ poorly, $2=$ neither poorly nor well, $3=$ well, $4=$ very well. Points are the mean scores (weighted in France) and bars are $95 \%$ confidence intervals. Points and lines in gray are for occupations that reflect national identity, points and lines in black are for occupations that do not reflect national identity. Beneath the $y$-axis labels is the difference between occupations that do and do not reflect national identity.

items, so prior to estimating the models I expand the data set so that each respondent has one observation for each occupation vignette. This allows me to estimate regression models where the dependent variable is the extent to which the vignette corresponds to the ideal image of a French, German, or American person and an independent variable is whether the respondent is answering the subset of occupation vignettes that reflect national identity. In addition, I address the likely correlation within respondents and across vignettes by robust standard errors clustered by respondent. ${ }^{15}$ 
Full results for the regression models are in Online Appendix Tables A4, A5, and A6 but the key findings are consistent with the above interpretation of Figure 1. In France and Germany, the coefficient for occupations that reflect national identity is roughly 3 times as large for native as opposed to immigrant-origin vignettes. In addition, I estimate models with interaction terms for the relationship between occupations that reflect national identity and whether the vignette describes a native or immigrant-origin character. These models suggest that occupations that reflect national identity have a stronger relationship with being considered an ideal French or German person for native as opposed to immigrant-origin vignettes. In the United States, the coefficients for occupations that reflect national identity are similar for native and immigrant-origin vignettes and an interaction term provides no evidence of differential relationships between occupations and being considered an ideal American for native as opposed to immigrant-origin vignettes.

In summary, results thus far provide evidence of a connection between occupation and national identity for both native and immigrant-origin individuals. It is worth noting that in all three countries the evaluations of native and immigrant-origin individuals are similar when in occupations that do not reflect national identity. This is an encouraging indication of how immigrant integration has developed, even among non-European-origin groups that are often stigmatized as difficult to integrate. However, the smaller benefits for immigrant as opposed to native-origin individuals in occupations that reflect national identity in France and Germany suggest that foreign origins may be a greater barrier to integration in those countries.

\section{Ethnocentric National Identity and Beliefs About Real-World Immigrant Presence in Occupations}

The results thus far are consistent with $\mathrm{H} 3$ as they suggest there are fewer barriers to immigrant integration in the United States because national identity is less ethnocentric. However, another interpretation is that U.S. respondents' willingness to associate immigrant-origin individuals with occupations that reflect national identity could be a function of demographics in the specific occupations chosen in the study. Entrepreneurship embodies key American cultural values, but it is also a professional path commonly pursued by immigrants who face barriers in the mainstream labor market (Waldinger, Aldrich, \& Ward, 1990). Similarly, being an inventor involves many of the same entrepreneurial traits. Therefore, American respondents may be willing to accept immigrant-origin entrepreneurs and inventors as ideal Americans because they believe those are common occupations for immigrant-origin individuals, while the same beliefs are not held by French 
and German respondents about the real-world presence of immigrant-origin individuals as chefs, winemakers, symphony employees, or brewers.

I address this concern by analyzing beliefs about the real-world immigrant presence in occupations. I ask a series of questions in each survey about the extent to which respondents believe immigrant-origin individuals are present in each occupation. ${ }^{16}$ Descriptive statistics are in Online Appendix Tables A1, $\mathrm{A} 2$, and $\mathrm{A} 3$, and they indicate that in all three countries, respondents believe immigrant-origin individuals are less present in the occupations that reflect national identity as opposed to the occupations that do not reflect national identity. Yet, German respondents have the largest spread between their beliefs about the extent to which immigrant-origin individuals are present in occupations that do and do not that reflect national identity, followed by France and then the United States (where respondents believe that immigrant-origin individuals are present in the two types of occupations to roughly the same extent). ${ }^{17}$ This is consistent with the rank ordering of which country is most and least ethnocentric in terms of national identity, as developed in the earlier literature review. However, these findings are observationally equivalent with the counter-argument that U.S. respondents only accept immigrant-origin individuals as entrepreneurs and inventors because they believe those are common real-world occupations for immigrant-origin individuals.

To adjudicate between the two explanations, I leverage the variation within each country in beliefs about immigrant-origin individuals' presence in occupations. If the results are driven by whether or not respondents believe immigrant-origin individuals are present in the occupations, we would expect no benefit for immigrant-origin individuals in occupations that reflect national identity among respondents in all three countries who believe that immigrant-origin individuals are not present in those occupations. In addition, we would expect benefits for immigrant-origin individuals in occupations that reflect national identity among respondents in all three countries who believe that immigrant-origin individuals are present in those occupations. However, if the relationship between occupation and attitudes is primarily about ethnocentric national identification, we would expect these relationships to hold only in France and Germany. But if attitudes in the United States are driven by a greater openness to including immigrant-origin individuals in the national identity, respondents should be more likely to view immigrant-origin individuals as ideal representatives of the nation when in occupations that reflect national identity, irrespective of their beliefs about immigrant-origin individuals' real-world presence in the occupations.

I estimate a series of regression models on the expanded data sets (where each respondent has one observation for each occupation vignette). Results are in Tables 2,3 , and 4 . In each table, I begin by estimating models only among 
Table 2. Predicting Responses to "the Ideal Image of a French Person" Among Subsets of French Respondents.

\begin{tabular}{|c|c|c|c|c|}
\hline & \multicolumn{2}{|c|}{ Only immigrant vignettes } & \multicolumn{2}{|c|}{ All vignettes } \\
\hline & (I) & $(2)$ & (3) & (4) \\
\hline & Not present & Present & Not present & Present \\
\hline $\begin{array}{c}\text { National identity } \\
\text { occupation }\end{array}$ & $0.04(0.04)$ & $0.22 * * *(0.06)$ & $0.04(0.04)$ & $0.22 * * *(0.06)$ \\
\hline $\begin{array}{l}\text { Native-origin } \\
\text { vignette }\end{array}$ & & & $-0.05(0.10)$ & $0.17(0.13)$ \\
\hline $\begin{array}{l}\text { Native } \times \text { National } \\
\text { Identity }\end{array}$ & & & $0.37 * * *(0.08)$ & $0.14(0.10)$ \\
\hline Constant & $2.37 * * *(0.07)$ & $2.40 * * *(0.10)$ & $2.37 * * *(0.07)$ & $2.40 * * *(0.10)$ \\
\hline Observations & 981 & 527 & $\mathrm{I}, 708$ & $\mathrm{I}, 002$ \\
\hline Respondents & 248 & 135 & 435 & 262 \\
\hline$R^{2}$ & .00 & .01 & .02 & .03 \\
\hline
\end{tabular}

Ordinary least squares regressions with robust standard errors (in parentheses) clustered by respondent. Weighted data. "National identity occupation" is whether the occupation reflects national identity ("I") or not ("O"). "Native-origin vignette" is whether the vignette describes a native-origin character ("I") or not ("0"). "Native $\times$ National Identity" is an interaction term of the previous two covariates. Models I and 2 are restricted to respondents who received vignettes with immigrant-origin characters. Models 3 and 4 are for respondents who received any of the four vignettes. In addition, Models I and 3 are restricted to respondents who believe immigrant-origin individuals are not employed ("somewhat absent" or "absent") in the food or wine industry. Models 2 and 4 are restricted to respondents who believe immigrantorigin individuals are employed ("somewhat present" or "very present") in the food or wine industry. I estimate alternate models (not presented) with ordinal logistic regression, which has the advantage of not assuming that the dependent variable is continuous. However, ordinal logistic regression models assume that the relationship between each independent variable and the dependent variable is the same for each interval in the dependent variable categories and Brant tests suggest that this assumption may be violated. Nonetheless, results are consistent across ordinary least squares and ordinal logistic regressions. $*_{p}<.05 . *_{p}<.01 . * * * p<.00 \mathrm{I}$.

the subset of the survey that receive immigrant-origin vignettes and I include a covariate for whether respondents are answering the questions about occupations that reflect national identity. In each table, Model 1 is further restricted to respondents who believe that immigrants are not present in the occupations that reflect national identity and Model 2 is restricted to respondents who believe immigrants are present in the occupations that reflect national identity.

In France and Germany, Model 1 suggests that for respondents who believe immigrant-origin individuals are not present in occupations that 
Table 3. Predicting Responses to "the Ideal Image of a German Person" Among Subsets of German Respondents.

\begin{tabular}{|c|c|c|c|c|}
\hline & \multicolumn{2}{|c|}{ Only immigrant vignettes } & \multicolumn{2}{|c|}{ All vignettes } \\
\hline & (I) & (2) & (3) & (4) \\
\hline & Not present & Present & Not present & Present \\
\hline $\begin{array}{l}\text { National identity } \\
\text { occupation }\end{array}$ & $0.04(0.04)$ & $0.07(0.08)$ & $0.04(0.04)$ & $0.07(0.08)$ \\
\hline $\begin{array}{l}\text { Native-origin } \\
\text { vignette }\end{array}$ & & & $0.07(0.08)$ & $0.46(0.24)$ \\
\hline $\begin{array}{l}\text { Native } \times \text { National } \\
\text { Identity }\end{array}$ & & & $0.18 * *(0.06)$ & $0.13(0.12)$ \\
\hline Constant & $2.50 * * *(0.07)$ & $2.56 * * *(0.14)$ & $2.50 * * *(0.07)$ & $2.56 * * *(0.14)$ \\
\hline Observations & 1,162 & 231 & 2,625 & 378 \\
\hline Respondents & 166 & 33 & 375 & 54 \\
\hline$R^{2}$ & .00 & .00 & .02 & .08 \\
\hline
\end{tabular}

Ordinary least squares regressions with robust standard errors (in parentheses) clustered by respondent. Weighted data. "National identity occupation" is whether the occupation reflects national identity ("I") or not ("0"). "Native-origin vignette" is whether the vignette describes a native-origin character ("I") or not ("0"). "Native $\times$ National Identity" is an interaction term of the previous two covariates. Models I and 2 are restricted to respondents who received vignettes with immigrant-origin characters. Models 3 and 4 are for respondents who received any of the four vignettes. In addition, Models I and 3 are restricted to respondents who believe immigrant-origin individuals are not employed ("somewhat absent" or "absent") at the symphony or in the food, wine, or beer industry. Models 2 and 4 are restricted to respondents who believe immigrant-origin individuals are employed ("somewhat present" or "very present") at the symphony or in the food, wine, or beer industry. I estimate alternate models (not presented) with ordinal logistic regression, which has the advantage of not assuming that the dependent variable is continuous. However, ordinal logistic regression models assume that the relationship between each independent variable and the dependent variable is the same for each interval in the dependent variable categories and Brant tests suggest that this assumption may be violated. Nonetheless, results are consistent across ordinary least squares and ordinal logistic regressions.

$*_{p}<.05 . * * p<.01$. ***p $<.001$.

reflect national identity, immigrant-origin individuals are not more likely to be considered ideal French or German people when in those occupations. ${ }^{18}$ However, Model 2 in Tables 2 and 3 indicates that for respondents who believe immigrant-origin individuals are present in occupations that reflect national identity, immigrant-origin individuals do benefit from being in such occupations. ${ }^{19}$ In contrast, Models 1 and 2 in Table 4 suggest that immigrant-origin individuals in the United States are more likely to be seen as 
Table 4. Predicting Responses to "the Ideal Image of an American" Among Subsets of U.S. Respondents.

\begin{tabular}{|c|c|c|c|c|}
\hline & \multicolumn{2}{|c|}{ Only immigrant vignettes } & \multicolumn{2}{|c|}{ All vignettes } \\
\hline & Not present & Present & Not present & Present \\
\hline & (I) & $(2)$ & (3) & (4) \\
\hline $\begin{array}{l}\text { National identity } \\
\text { occupation }\end{array}$ & $0.49 * * *(0.08)$ & $0.28 * * *(0.08)$ & $0.49 * * *(0.08)$ & $0.28^{* * * *}(0.08)$ \\
\hline $\begin{array}{l}\text { Native-origin } \\
\text { vignette }\end{array}$ & & & $-0.16(0.11)$ & $-0.19(0.12)$ \\
\hline $\begin{array}{l}\text { Native } \times \text { National } \\
\text { Identity }\end{array}$ & & & $0.05(0.11)$ & $0.02(0.13)$ \\
\hline Constant & $2.84 * * *(0.09)$ & $3.10 * * *(0.08)$ & $2.84 * * *(0.09)$ & $3.10 * * *(0.08)$ \\
\hline Observations & 300 & 310 & 720 & 530 \\
\hline Respondents & 60 & 62 & 144 & 106 \\
\hline$R^{2}$ & .08 & .03 & .10 & .05 \\
\hline
\end{tabular}

Ordinary least squares regressions with robust standard errors (in parentheses) clustered by respondent. "National identity occupation" is whether the occupation reflects national identity ("I") or not ("O"). "Native-origin vignette" is whether the vignette describes a native-origin character ("I") or not ("O"). "Native $\times$ National Identity" is an interaction term of the previous two covariates. Models I and 2 are restricted to respondents who received vignettes with immigrant-origin characters. Models 3 and 4 are for respondents who received any of the four vignettes. In addition, Models I and 3 are restricted to respondents who believe immigrant-origin individuals are not employed ("somewhat absent" or "absent") as entrepreneurs or inventors. Models 2 and 4 are restricted to respondents who believe immigrant-origin individuals are employed ("somewhat present" or "very present") as entrepreneurs and inventors. I estimate alternate models (not presented) with ordinal logistic regression, which has the advantage of not assuming that the dependent variable is continuous. However, ordinal logistic regression models assume that the relationship between each independent variable and the dependent variable is the same for each interval in the dependent variable categories and Brant tests suggest that this assumption may be violated. Nonetheless, results are consistent across ordinary least squares and ordinal logistic regressions.

$*_{p}<.05 . *_{p}<.01 . * *_{p}<.001$.

ideal representatives of the nation when in occupations that reflect national identity, regardless of whether respondents believe immigrant-origin individuals are present in such occupations in the real world.

Models 3 and 4 are for respondents across all vignette conditions. The key covariate of interest is the interaction term for the relationship between receiving a native-origin vignette and answering a question about occupations that reflect national symbolism. Model 3 is restricted to respondents who believe that immigrants are not present in the occupations that reflect 
national identity and the interaction term is positive and statistically significant in France (at $p<.001$ ) and in Germany (at $p<.01$ ). However, Model 4 in both tables is the subset of the respondents who believe that immigrantorigin individuals are present in occupations that reflect national identity. For these respondents, there is no statistically significant (at $p<.05)$ difference in the increase for being seen as an ideal French or German person among natives as opposed to immigrant-origin individuals in occupations that reflect national identity. However, among U.S. respondents in Table 4, the coefficient for the interaction term is small and not statistically significant (at $p<.05$ ) for either subset of respondents. This suggests that-unlike in France and Germany-U.S. respondents' willingness to view immigrantorigin entrepreneurs and inventors as ideal representatives of the nation is not influenced by perceptions of the demographics of the occupations but is more focused on the fact that the occupations reflect national identity. Overall, results in this section support $\mathrm{H} 3$ and are consistent with the notion that a more ethnocentric national identity in Germany and France creates more barriers for immigrant-origin individuals being seen as ideal representatives of the nation.

\section{Alternative Interpretations}

To probe the robustness of results from the previous sections, I explore two alternative interpretations of the findings. I first explore whether respondents have different opinions about which occupations reflect national identity. I then explore whether material concerns are a more useful way of interpreting variation in attitudes across immigrant occupations.

\section{Different Conceptions of National Identity}

For the analysis thus far, I use secondary literature and pilot surveys to select occupations that reflect national identity. However, respondents may have different opinions about the extent to which different occupations reflect national identity. This could challenge my interpretation of the findings because it could mean that something other than national identity is causing respondents to evaluate some vignettes as more representative of the nation than others.

To explore how respondents view each occupation, I pose a series of questions about the importance of each occupation for national cultural identity. ${ }^{20}$ Descriptive statistics are in Online Appendix Tables A1, A2, and A3. The results suggest that German and American opinions of occupations that reflect national identity are consistent with my expectations. In Germany, brewers are seen as the most important occupation for national 
cultural identity, followed by chefs, symphony employees, and winemakers. In the United States, entrepreneurs are seen as the most important occupation for national cultural identity and inventors are the second most important. In addition, $t$ tests indicate that for German and U.S. respondents there is a statistically significant (at $p<.001$ for one-tailed tests) difference in the mean importance for national identity between the occupations that I code as reflecting national identity and those that I code as not reflecting national identity.

Results from France are partially consistent with my expectations. Chefs have the most importance for national cultural identity, but civil servant is the second most important occupation, followed by winemaker and then banker. This could suggest that something other than national identity is driving the results in Figure 1, where chefs and winemakers are viewed as more representative of the nation than civil servants and bankers. However, graphs in Online Appendix Figure A4 disaggregate the mean ideal image score across occupations and indicate that in France, chefs, winemakers, and civil servants are seen as the best representatives of France among both immigrant and native-origin vignettes. Accordingly, banker is the occupation that is clearly the least likely to be considered an ideal French person. This suggests that my expectations for which occupations reflect French national identity may not have been accurate, but the underlying logic still holds as the occupations that are considered most reflective of national identity are the vignettes rated the most representative of the nation. ${ }^{21}$

\section{Occupation and Material Concerns}

I explore the cultural connection between occupation and national identity, but a more common approach is to analyze how natives view immigrant occupation through the lens of material concerns and whether or not the immigrant will be economically beneficial for society (Helbling \& Kriesi, 2014). Therefore, respondents' evaluations of the vignettes may be driven more by beliefs about how the occupations contribute to society than by whether the occupations culturally reflect national identity. I explore this possibility in two ways.

First, I explore the potential importance of socio-economic status. ${ }^{22}$ I randomly assign respondents to receive vignettes that are either all high or low socio-economic status versions of the occupation. Figure 2 presents mean scores on the dependent variable across occupations for low and high socio-economic status vignettes. For the most part, results are consistent with those presented in Figure 1. Both high- and low-status native and immigrant-origin individuals benefit from being in 


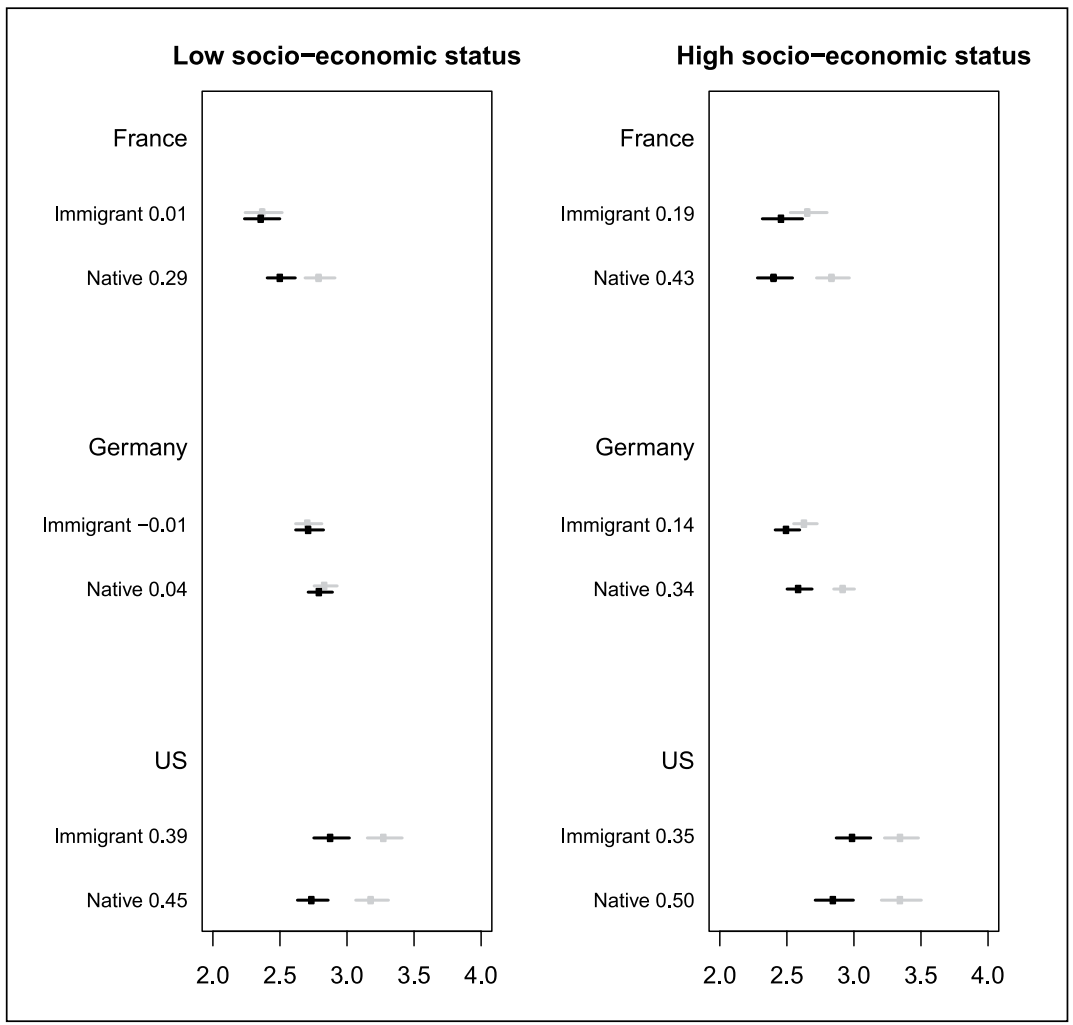

Figure 2. Mean scores for the ideal image of a French/German/American person across occupations and socio-economic status.

The dependent variable is coded $0=$ very poorly, I = poorly, $2=$ neither poorly nor well, $3=$ Well, $4=$ very well. Points are the mean scores (weighted in France) and bars are $95 \%$ confidence intervals. Points and lines in gray are for occupations that reflect national identity, points and lines in black are for occupations that do not reflect national identity. Beneath the $y$-axis labels is the difference between occupations that do and do not reflect national identity. "Low socioeconomic status" and "high socio-economic status" refer to the characters in the vignettes.

occupations that reflect national identity. However, in France and Germany, the benefits to immigrant-origin individuals are modest and smaller than the benefits for native-origin individuals. In the United States, immigrant and native-origin individuals have roughly the same benefit for being in occupations with national symbolism, among low and high socio-economic status vignettes. ${ }^{23}$

A second way in which material concerns may be relevant is that respondents may evaluate vignette characters more favorably when they believe 
the occupation has more economic benefit for the nation (irrespective of socio-economic status). If this were true, the evaluations of some vignettes as more representative of the nation could be motivated by concerns about material benefits to society and not by whether the occupation reflects national identity. To explore this possibility, I pose a series of questions about respondents' views on the importance of each occupation for national material prosperity. ${ }^{24}$ Descriptive statistics are in Online Appendix Tables A1, A2, and A3. For France and Germany, the results indicate no correspondence between the occupations seen as most materially important and the occupations seen as most representative of an ideal French or German person. $^{25}$

U.S. respondents consider entrepreneurs and inventors to be the most economically and culturally important occupations. This suggests that respondents' evaluation of entrepreneurs and inventors is likely influenced both by cultural associations with national identity and material calculations about economic benefits for society. To evaluate the relative importance of each influence, I estimate a series of regression models in which the dependent variable is the question about whether the vignette corresponds to the ideal image of an American. Unlike in previous analyses, each model is limited to questions about one occupation (either entrepreneur or inventor). In each model, I include a covariate for respondents' views on the material importance of the respective occupation and a covariate for respondents' views on the cultural importance of the respective occupation. ${ }^{26}$ The models suggest that variation in views about material importance is slightly more important than variation in views about cultural importance. Predicted scores on the ideal American dependent variable are the same among respondents who believe that entrepreneurs and inventors are materially and culturally important. Yet there is a steeper decline in being seen as an ideal American as respondents believe that entrepreneurs and inventors are less materially important (as opposed to less culturally important). ${ }^{27}$

In some respects, the importance of economic considerations is consistent with the particularities of entrepreneurs and inventors because both occupations are heavily commercial. Future research could explore whether these overlapping economic and cultural considerations also exist for other occupations that may be seen as ideally American. This is a definite possibility given the tradition of capitalism and economic individualism as core American values (Theiss-Morse, 2009). Nonetheless, it is worth noting that even if the results in Figure 1 are motivated by cultural and economic interpretations of the occupations, the finding remains that immigrant-origin individuals receive greater benefits for being in nationally significant occupations in the United States as opposed to in France or Germany. 


\section{Conclusion}

This article has explored the relationships between occupation, national identity, and immigrant integration. One of the main findings is that immigrant and native-origin individuals are more likely to be viewed as ideal representatives of the nation when employed in occupations that reflect national identity. This suggests a new way of analyzing the multifaceted role that national identity boundaries play in everyday life. My focus is on the marginal benefit of being in an occupation that reflects national identity, so the results do not imply that choosing the right occupation is the only (or even the most important) way to be seen as an ideal representative of the nation. However, these benefits are likely to be especially important for non-European-origin immigrant-origin individuals who are often stigmatized and excluded from the national community on the basis of having foreign origins, despite having achieved "objective" integration indicators like citizenship and language fluency.

Another central finding is that the relationship between occupation, national identity, and immigrant integration may vary across country contexts. Immigrant-origin individuals in countries like France and Germany where national identity is more ethnocentric may only receive minimal benefits for working in occupations that reflect national identity. In both countries, immigrant-origin individuals benefit from being in occupations that reflect national identity, but the increase in being seen as an ideal representative of the nation is substantively modest. In addition, the increase in being seen as an ideal representative of the nation for immigrant-origin individuals in France and Germany is only one third the size of the increase for nativeorigin individuals. This suggests that the immigrant-native boundary has deeper salience in these countries. In contrast, immigrant-origin individuals in the United States - where national identity is less ethnocentric - receive the same benefit as native-origin individuals for being in an occupation that reflects national identity. This does not imply that foreign origins are irrelevant for immigrant-origin individuals in the United States or that immigrantorigin individuals do not face any stigmatization or structural exclusion in the United States. Instead, it suggests that immigrant-origin individuals have a greater chance of being seen as legitimate members of the national community when they adopt mainstream cultural norms, which is consistent with recent research on immigrant-native identity boundaries in the United States (Alba \& Foner, 2015; Maxwell \& House, 2016).

One goal of this article was to establish a plausible connection between occupation, national identity, and immigrant integration. Yet there are many ways in which these relationships could operate. I focus on occupations that reflect a range of national identity cultural markers, but some occupations 
(e.g., police, military, government officials) literally represent the nation. For these occupations, native respondents might be more likely to feel threatened when immigrant-origin individuals literally represent the nation because immigrant-origin individuals are considered insufficiently trustworthy for such sensitive occupations (Yogeeswaran, Dasgupta, Adelman, Eccleston, \& Parker, 2011). Another way of conceptualizing occupation is at the industry or sectoral level. Recent research suggests that natives in Europe are more likely to feel threatened by immigrants and have negative attitudes about immigration when they work in sectors with large inflows of immigrants and when economic conditions deteriorate (Dancygier \& Donnelly, 2013). This suggests that the role of immigrant occupation in shaping integration may also operate at a broader level of aggregation than the specific jobs used in this article. In addition, natives may feel a cultural competition to represent the nation that is primarily activated when they share an occupation or an industry with many immigrant-origin individuals. It is also possible that natives' responses to immigrant-origin individuals in occupations that reflect national identity depend on natives' level or type of attachment to national identity (Huddy \& Khatib, 2007). Finally, this article focused on attitudes toward specific non-European-origin male immigrant-origin individuals, but the relationship between occupation and national identity may differ for women or for other immigrant-origin groups. All of these issues are beyond the scope of this current study but offer promising avenues for future research.

Overall, the findings in this article are both optimistic and pessimistic about the prospects for immigrant integration. Some of the most promising evidence of successful integration is the fact that immigrant and native-origin individuals in occupations that do not reflect national identity are considered equally ideal representatives of the nation in all three countries. In addition, there is evidence that immigrant-origin individuals can use occupational choice as a strategy for signaling their commitment to the national community. Nonetheless, in countries like France and Germany, the non-European foreign origins are likely to continue to structure integration outcomes for the foreseeable future.

\section{Author's Note}

Previous versions of the article were presented at University of Massachusetts, Amherst, Cornell University, SPIRE conference Rutgers University, the Annual Meeting of the American Political Science Association, University of Vienna, University of Göttingen, the Berlin Social Science Research Center (WZB), the International Society of Political Psychology annual meeting, University of Manchester, University of Sussex, University of North Carolina at Chapel Hill, and Johns Hopkins University. 


\section{Acknowledgments}

The author thanks Daniel Butler, Pamela Conover, Bruce Desmarais, Ruth Ditlmann, Peter Enns, Jeremy Ferwerda, Sebastian Fietkau, Silke Hans, Matthias Koenig, Jan Kubik, Alexander Kuo, Ray LaRaja, Morris Levy, Simon Maag, Michael MacKuen, Ines Michalowski, Tatishe Nteta, Jesse Rhodes, Brian Schaffner, Karen Schönwälder, Nina Söhn, Florian Stoeckel, Alexander Street, Nicholas Valentino, Matthew Wright, Malisa Zobel, and the anonymous reviewers for helpful comments on earlier versions.

\section{Declaration of Conflicting Interests}

The author(s) declared no potential conflicts of interest with respect to the research, authorship, and/or publication of this article.

\section{Funding}

The author(s) disclosed receipt of the following financial support for the research, authorship, and/or publication of this article: Funding for this research was made possible by University of Massachusetts, Amherst, and University of North Carolina at Chapel Hill.

\section{Notes}

1. See, for example, Goodman (2015) or the special issue of Comparative Political Studies titled "Immigration and Citizenship Policy Research," edited by Marc Helbling and Ines Michalowski.

2. The French survey was conducted between March 18 and 21,2013, by YouGovFrance. The German survey was conducted between April 23 and 25, 2014, by the market research company Dr. Grieger \& Cie Marktforschung. The U.S. survey was conducted on Amazon's Mechanical Turk (MTurk) platform on April 29, 2014. Details on each survey are in the "Survey Design" section of the online appendix.

3. This is the standard practice for research on attitudes about immigrants (Hainmueller \& Hopkins, 2014). There is evidence that immigrant-origin individuals have attitudes about immigration that differ from those of native-origin individuals (Carter \& Pérez, 2016), so I leave the investigation of their attitudes for future studies.

4. Full details on all procedures are in the "Survey Design" section of the online appendix.

5. The French wording is "Dans quelle mesure corréspond NAME à votre image idéale d'un français?" and in German it is "Wie gut entspricht NAME Ihrem Bild eines vorbildlichen Deutschen?" Response options are a 5-point Likert-type scale ranging from very poorly to very well.

6. To confirm that this is not just a stereotype among researchers but also a belief held among the general population, I conducted a pilot study in France that asks about the importance of several occupations for French national identity and the results are consistent with the expectation that gastronomy is a key part of French identity. More details are in the "Survey Design" section of the online appendix. 
7. Another common response was cowboy, which has important historical cultural symbolism. However, cowboys are not very common today and the vignettes might have provoked strange or confused responses. In addition, cowboy is not amenable to being depicted as both a high and low socio-economic status occupation, which was a necessary feature of my survey design as described in the next section.

8. For example, neither engineer nor janitor satisfies this criterion.

9. This does not imply that food and wine are unimportant to Americans, or that Americans do not construct their individual identities based on food and wine preferences or consumption patterns. Instead, the key distinction is that chefs and winemakers are not central components of American national identity.

10. The distinction between immigrant and native origins is signaled with photos in France and with names in Germany and the United States. Full details are in the "Survey Design" section of the online appendix.

11. It is beyond the scope of this article to explore variation in responses to different non-European-origin groups. It is possible that some immigrant groups are more or less likely to be associated with occupations that have specific meaning for national identity. It is also possible that the main difference across immigrant groups in the same country would be the overall likelihood of being considered a representative of the nation, without significant differences in the pattern across occupations.

12. Note that this design does not obscure the fact that respondents are being analyzed for how they evaluate individuals in different occupations. Another option would be to present each respondent with only one randomly assigned occupation vignette. However, to get a sufficiently large set of occupations to enable reasonable inferences, I would need a much larger sample size, which was not feasible.

13. I do not vary the level of cultural assimilation, time spent in the host country, or whether or not the immigrant-origin individual was born abroad. All of these factors have been shown to affect natives' willingness to accept immigrant-origin individuals (Hainmueller \& Hopkins, 2015), but a detailed analysis of each factor is beyond the scope of this article.

14. More detailed results for each occupation and each response category are in Online Appendix Figures A1, A2, and A3.

15. Results are substantively similar with classical standard errors and without clustering.

16. These questions were asked after the vignettes. Another option would be to use data on the actual number of immigrant-origin individuals in each occupation. However, these data are not collected according to the occupation and immigrant categories that I use in this article. In addition, research suggests that most people incorrectly estimate the racial, ethnic, and immigrant-origin composition of their neighborhood and their country (Koopmans \& Schaeffer, 2016; Wong, 2007). This can happen for many reasons, including the difficulty of making demographic calculations about a large geographical space while only having 
interacted with a particular (non-random) sample of that population. Therefore, subjective perceptions of immigrant demographics are more important than objective demographic data for understanding attitude formation (Semyonov, Raijman, \& Gorodzeisky, 2008).

17. After recoding the measures to run from 0 to 1 because of different scales across countries, there is a gap of 0.15 points in Germany between the mean score for immigrant presence in the occupations that reflect as opposed to do not reflect national identity. The gap is 0.05 points in France and 0.03 points in the United States.

18. These coefficients are not statistically significant at the $5 \%$ level.

19. There is a more dramatic difference between Models 1 and 2 in France, where the coefficient is more than 5 times as large and is statistically significant at $p$ $<.001$ in Model 2. In Germany, the coefficient is almost twice as large in Table 2 , but it is not statistically significant (at $p<.05$ ). This is most likely an issue of limited statistical power. There are more occupations that reflect national identity in the German survey so there are only 33 German respondents who believe that immigrant-origin individuals are present in all four occupations that reflect national identity.

20. These questions were asked after the vignettes.

21. Another outcome of note in Online Appendix Figure A4 is that the four German occupations seen as most reflective of national identity do not all yield the same benefits for being seen as an ideal German. Chefs and winemakers have the highest mean ideal image scores (among both native and immigrant-origin vignettes) but brewers and symphony employees are considered just as representative as civil servants and retail employees, despite being considered more reflective of national identity. This may suggest a nuanced disconnect between certain kinds of occupations (e.g., brewers and symphony employees) that evoke strong national symbols (e.g., drinking beer and listening to classical music) but for which the individual employees do not necessarily embody that national identity to the same extent as other occupations. Future research can explore this more closely.

22. Existing literature finds that high socio-economic status immigrants are generally preferable to low socio-economic status immigrants because they are seen as more economically beneficial for society (Hainmueller \& Hiscox, 2010; Hainmueller \& Hopkins, 2015).

23. Admittedly, for both immigrant and native-origin individuals in France and Germany, there is a greater increase in being seen as an ideal representative of the nation when in high- as opposed to low-status occupations that reflect national identity. This suggests that there may be an additional element of socioeconomic status that is correlated with being seen as a better representative of the nation in France and Germany. Future research could explore whether these dynamics are a function of the specific occupations in this study or a more general trend. But for the purposes of analyzing immigrant integration, the main results are consistent irrespective of socio-economic status. 
24. These questions were asked after the vignettes.

25. In France, winemakers are seen as the least economically important of the four occupations despite being seen as one of the most representative of an ideal French person in Online Appendix Figure A4. In Germany, bankers are considered the most economically important despite being seen as the least representative of an ideal German in Online Appendix Figure A4.

26. Full results from the regression models are in Online Appendix Table A7 and post-estimation graphs of the predicted scores across different evaluations of the material and cultural importance of the respective occupation are in Online Appendix Figures A5 and A6.

27. For one subsample - attitudes about native-origin inventors - there is no statistically significant difference between material and cultural importance as predictors of attitudes.

\section{References}

Aalberg, T., Iyengar, S., \& Messing, S. (2011). Who is a "deserving" immigrant? An experimental study of Norwegian attitudes. Scandinavian Political Studies, 35, 97-116.

Adida, C., Laitin, D., \& Valfort, M.-A. (2014). Muslims in France: Identifying a discriminatory equilibrium. Journal of Population Economics, 27, 1039-1086.

Alba, R., \& Foner, N. (2015). Strangers no more: Immigration and the challenges of integration in North America and Western Europe. Princeton, NJ: Princeton University Press.

Alba, R., \& Nee, V. (2003). Remaking the American mainstream: Assimilation and contemporary immigration. Cambridge, MA: Harvard University Press.

Anderson, B. (1983). Imagined communities: Reflections on the origin and spread of nationalism. London, England: Verso.

Bail, C. (2008). The configuration of symbolic boundaries against immigrants in Europe. American Sociological Review, 73, 37-59.

Bettencourt, A. B., Dill, K., Greathouse, S., Charlton, K., \& Mulholland, A. (1997). Evaluations of ingroup and outgroup members: The role of category-based expectancy violation. Journal of Experimental Social Psychology, 33, 244-275.

Billig, M. (1995). Banal nationalism. London, England: Sage.

Blumer, H. (1969). Symbolic interactionism: Perspective and method. Englewood, NJ: Prentice Hall.

Bourdieu, P. (1987). What makes a social class? On the theoretical and practical existence of groups. Berkeley Journal of Sociology, 32, 1-17.

Brown, R. (2010). Prejudice: Its social psychology (2nd ed.). Malden, MA: WileyBlackwell.

Brubaker, R. (1992). Citizenship and nationhood in France and Germany. Cambridge, MA: Harvard University Press.

Butz, D. (2009). National symbols as agents of psychological and social change. Political Psychology, 30, 779-804. 
Caldwell, C. (2009). Reflections on the revolution in Europe: Immigration, Islam and the West. New York, NY: Doubleday.

Carter, N., \& Pérez, E. (2016). Race and nation: How racial hierarchy shapes national attachments. Political Psychology, 37, 497-513.

Corneo, G., \& Jeanne, O. (2010). Symbolic values, occupational choice, and economic development. European Economic Review, 54, 237-251.

Dancygier, R. (2010). Immigration and conflict in Europe. New York, NY: Cambridge University Press.

Dancygier, R., \& Donnelly, M. (2013). Sectoral economies, economic contexts, and attitudes toward immigration. Journal of Politics, 75, 17-35.

Dancygier, R., \& Laitin, D. (2014). Immigration into Europe: Economic discrimination, violence, and public policy. Annual Review of Political Science, 17, 43-64.

DeSoucey, M. (2010). Gastronationalism: Food traditions and authenticity politics in the European Union. American Sociological Review, 75, 432-455.

Ditlmann, R., Purdie-Vaughns, V., \& Eibach, R. (2011). Heritage- and ideology-based national identities and their implications for immigrant citizen relations in the United States and in Germany. International Journal of Intercultural Relations, 35, 395-405.

Dunkerley, D. (2013). Occupations and society. Oxon, UK: Routledge.

Enos, R. (2014). Causal effect of intergroup contact on exclusionary attitudes. Proceedings of the National Academy of Sciences, 111, 3699-3704.

Fassin, D., \& Fassin, E. (2006). De la question sociale à la question raciale? [From the social question to the racial question?]. Paris, France: La Découverte.

Ferguson, P. (1998). A cultural field in the making: Gastronomy in 19th century France. American Journal of Sociology, 104, 597-641.

Flores, R. (2015). The resurgence of race in Spain: Perceptions of discrimination among immigrants. Social Forces, 94, 237-269.

Goldstein, J., \& Stecklov, G. (2016). From Patrick to John F.: Ethnic names and occupational success in the last era of mass migration. American Sociological Review, 81, 85-106.

Goodman, S. (2012). Fortifying citizenship: Policy strategies for civic integration in Western Europe. World Politics, 64, 659-698.

Goodman, S. (2015). Conceptualizing and measuring citizenship and integration policy: Past lessons and new approaches. Comparative Political Studies, 48, 1905-1941.

Guy, K. (2007). When champagne became French: Wine and the making of a national identity. Baltimore, MD: Johns Hopkins University Press.

Hainmueller, J., \& Hangartner, D. (2013). Who gets a Swiss passport? A natural experiment in immigrant discrimination. American Political Science Review, 107, 159-187.

Hainmueller, J., \& Hiscox, M. (2010). Attitudes toward highly skilled and low-skilled immigration: Evidence from a survey experiment. American Political Science Review, 104, 61-84.

Hainmueller, J., \& Hopkins, D. (2014). Public attitudes toward immigration. Annual Review of Political Science, 17, 225-249. 
Hainmueller, J., \& Hopkins, D. (2015). The hidden American immigration consensus: A conjoint analysis of attitudes toward immigrants. American Journal of Political Science, 59, 529-548.

Hauser, R., \& Featherman, D. (1977). The process of stratification: Trends and analyses. Ann Arbor: University of Michigan Press.

Helbling, M., \& Kriesi, H. (2014). Why citizens prefer high- over low-skilled immigrants. Labor market competition, welfare state, and deservingness. European Sociological Review, 30, 595-614.

Helbling, M., \& Traunmüller, R. (2016). How state support of religion shapes attitudes toward Muslim immigrants. New evidence from a subnational comparison. Comparative Political Studies, 49, 391-424.

Hochschild, J., \& Mollenkopf, J. (Eds.). (2009). Bringing outsiders in: Transatlantic perspectives on immigrant political incorporation. Ithaca, NY: Cornell University Press.

Hopkins, D. (2015). The upside of accents: Language, inter-group difference, and attitudes toward immigration. British Journal of Political Science, 45, 531-557.

Huddy, L., \& Khatib, N. (2007). American patriotism, national identity, and political involvement. American Journal of Political Science, 51, 63-77.

Huntington, S. (2004). Who are we? The challenges to America's national identity. New York, NY: Simon \& Schuster.

Joppke, C. (2007). Transformation of immigrant integration: Civic integration and antidiscrimination in the Netherlands, France, and Germany. World Politics, 59, 243-273.

Kernahan, C., Bartholow, B., \& Bettencourt, A. B. (2000). Effects of category-based expectancy violation on affect-related evaluations: Toward a comprehensive model. Basic and Applied Social Psychology, 22, 85-100.

Koopmans, R., \& Schaeffer, M. (2016). Statistical and perceived diversity and their impacts on neighborhood social cohesion in Germany, France and the Netherlands. Social Indicators Research, 125, 853-883.

Koopmans, R., Statham, P., Giugni, M., \& Passy, F. (2005). Contested citizenship: Immigration and cultural diversity in Europe. Minneapolis: University of Minnesota Press.

Lepenies, W. (2006). The seduction of culture in German history. Princeton, NJ: Princeton University Press.

Li, Q., \& Brewer, M. (2004). What does it mean to be an American? Patriotism, nationalism, and American identity after 9/11. Political Psychology, 25, 727-739.

Maxwell, R. (2012). Ethnic minority migrants in Britain and France: Integration trade-offs. New York, NY: Cambridge University Press.

Maxwell, R., \& House, L. (2016). Judging the character of people who insult the nation: Implications for immigrant integration. Unpublished manuscript.

Mendes, W., Blascovich, J., Hunter, S., Lickel, B., \& Jost, J. (2007). Threatened by the unexpected: Physiological responses during social interactions with expectancyviolating partners. Journal of Personality and Social Psychology, 92, 698-716.

Newman, B., Hartman, T., \& Taber, C. (2012). Foreign language exposure, cultural threat, and opposition to immigration. Political Psychology, 33, 635-657. 
Noiriel, G. (1988). Le creuset français: Histoire de l'immigration, xixe - xxe siècles [The French Melting Pot: Immigration, Citizenship, and National Identity]. Paris, France: Éditions Seuil.

Orgad, L. (2015). The cultural defense of nations: A liberal theory of majority rights. Oxford, UK: Oxford University Press.

Reeskens, T., \& Wright, M. (2013). Nationalism and the cohesive society: A multilevel analysis of the interplay among diversity, national identity, and social capital across 27 European societies. Comparative Political Studies, 46, 153-181.

Rose, D., \& Harrison, E. (Eds.). (2010). Social class in Europe: An introduction to the European socio-economic classification. Oxon, UK: Routledge.

Ross, L., \& Nisbett, R. (1991). The person and the situation: Perspectives of social psychology. Philadelphia, PA: Temple University Press.

Schatz, R., \& Lavine, H. (2007). Waving the flag: National symbolism, social identity, and political engagement. Political Psychology, 28, 329-355.

Schildkraut, D. (2010). Americanism in the twenty-first century: Public opinion in the age of immigration. New York, NY: Cambridge University Press.

Schildkraut, D. (2014). Boundaries of American identity: Evolving understandings of "us." Annual Review of Political Science, 17, 441-460.

Semyonov, M., Raijman, R., \& Gorodzeisky, A. (2008). Foreigners' impact on European societies: Public views and perceptions in a cross-national comparative perspective. International Journal of Comparative Sociology, 49, 5-29.

Smith, A. (1991). National identity. London, England: Penguin Books.

Sniderman, P., \& Hagendoorn, L. (2007). When ways of life collide: Multiculturalism and its discontents in the Netherlands. Princeton, NJ: Princeton University Press.

Stangor, C., \& Ford, T. (1992). Accuracy and expectancy-confirming processing orientations and the development of stereotypes and prejudice. European Review of Social Psychology, 3, 57-89.

Sue, C., \& Telles, E. (2007). Assimilation and gender in naming. American Journal of Sociology, 112, 1383-1415.

Tajfel, H. (1974). Social identity and intergroup behavior. Social Science Information, 13(2), 65-93.

Theiss-Morse, S. (2009). Who counts as an American? The boundaries of national identity. New York: Cambridge University Press.

Tribalat, M. (1995). Faire france: une enquête sur les immigrés et leurs enfants [Making France: A survey of immigrants and their children]. Paris, France: La Découverte.

Waldinger, R., Aldrich, H., \& Ward, R. (1990). Ethnic entrepreneurs: Immigrant business in industrial societies. Newbury Park, CA: Sage.

Wimmer, A., \& Soehl, T. (2014). Blocked acculturation: Cultural heterodoxy among Europe's immigrants. American Journal of Sociology, 120, 146-186.

Wong, C. (2007). "Little" and "big" pictures in our heads: Race, local context, and innumeracy about racial groups in the United States. Public Opinion Quarterly, $71,392-412$.

Wong, C. (2010). Boundaries of obligation in American politics: Geographic, national, and racial communities. New York, NY: Cambridge University Press. 
Wright, M. (2011a). Diversity and the imagined community: Immigrant diversity and conceptions of national identity. Political Psychology, 32, 837-862.

Wright, M. (2011b). Policy regimes and normative conceptions of nationalism in mass public opinion. Comparative Political Studies, 44, 598-624.

Wright, M., \& Citrin, J. (2011). Saved by the stars and stripes? Images of protest, salience of threat, and immigration attitudes. American Politics Research, 39, 323-343.

Wright, M., Levy, M., \& Citrin, J. (2016). Public attitudes toward immigration policy across the legal/illegal divide: The role of categorical and attribute-based decision-making. Political Behavior, 38, 229-253.

Yogeeswaran, K., \& Dasgupta, N. (2014). Conceptions of national identity in a globalised world: Antecedents and consequences. European Review of Social Psychology, 25, 189-227.

Yogeeswaran, K., Dasgupta, N., Adelman, L., Eccleston, A., \& Parker, M. (2011). To be or not to be (ethnic): Public vs. private expressions of ethnic identification differentially impact national inclusion of white and non-white groups. Journal of Experimental Social Psychology, 47, 908-914.

\section{Author Biography}

Rahsaan Maxwell is an Associate Professor in the Department of Political Science at the University of North Carolina, Chapel Hill. His research explores the politics of racial, ethnic, religious, and immigrant-origin minorities, often focusing on Western Europe. He has examined numerous issues including minority political attitudes, identity, representation, discrimination and assimilation. 